\title{
PROTEIN PEROXIDE OXIDATION IN THE CEREBRAL CORTEX AND HIPPOCAMPUS OF RATS WITH TYPE 2 DIABETES MELLITUS, UNDER CARBACETAM EFFECT
}

\author{
Olga G. KMET ${ }^{1} \bowtie$, Nataliia D. FILIPETS ${ }^{1}$, Tamara I. HRACHOVA ${ }^{1}$, Yurii M. VEPRIUK ${ }^{1}$, \\ Kateryna V. VLASOVA ${ }^{1}$ \\ ${ }^{1}$ Higher State Educational Establishment of Ukraine „Bukovinian State Medical University“, Chernivtsi, \\ Ukraine
}

\author{
Received 01 July 2019, Accepted 15 August 2019 \\ https://doi.org/10.31688/ABMU.2019.54.3.05
}

\section{Abstract}

Introduction. One of medical-social chronic consequences of diabetes mellitus is encephalopathy, with an advancing course and development of neurodegenerative disorders in the central nervous system.

Objective: to examine carbacetam effect as a new modulator of gamma-aminobutyric acid activity on protein peroxide oxidation and morphological condition of the cerebral cortex and hippocampus in rats under conditions of experimental neurodegeneration in case of type 2 diabetes mellitus.

Materials and methods. Changes in the content of protein peroxide oxidation in the cerebral cortex and hippocampus under effect of carbacetam $(5 \mathrm{mg}$ ) $\mathrm{kg}$ ) are examined in nonlinear laboratory albino male rats with neurodegeneration under conditions of type 2 diabetes mellitus simulated by streptozotocin and high-fat diet.

Results. In rats with type 2 diabetes mellitus, the degree of protein peroxide oxidation in the cerebral cortex and hippocampus increases, which is associated with increased amount of cells with karyopyknosis,
\end{abstract}

\section{Résumé}

L'oxydation au peroxyde des protéines et l'état morphologique du cortex cérébral et de l'hippocampe des rats présentant une neurodégénérescence avec diabète sucré de type 2 sous l'effet du carbacétam

Introduction. Une des conséquences médicales et sociales chroniques du diabète de type 2 est une encéphalopathie à l'évolution et au développement progressifs des troubles neurodégénératifs du système nerveux central.

Le but de l'étude était d'étudier l'effet du carbacétam, un nouveau modulateur de l'activité de l' acide gamma-aminobutyrique, sur l'oxydation des protéines par le peroxyde, ainsi que l'état morphologique du cortex cérébral et de l'hippocampe dans des conditions de neurodégénérescence expérimentale dans le diabète de type 2.

Matériaux et méthodes. Des modifications de la teneur en produits de l'oxydation au peroxyde du cortex cérébral et des protéines de l'hippocampe sous l'influence du carbacétam $(5 \mathrm{mg} / \mathrm{kg})$ chez des rats blancs 
decreased relative density of staining of the neuron tigroid substance and partial denudation of vessels. After carbacetam administration during 14 days in rats with type 2 diabetes mellitus in the cerebral cortex and hippocampus the level of protein peroxide oxidation decreases, the amount of cells with karyopyknosis reduces, a relative density of staining of the neuron tigroid substance increases, and denudation of vessels is lacking.

Conclusions. Decreased intensity of the protein peroxide oxidation processes, histological destruction of the cerebral cortex and hippocampus are indicative of a neuroprotective potential of carbacetam under conditions of neurodegeneration caused by type 2 diabetes mellitus.

Keywords: type 2 diabetes mellitus, neurodegeneration, carbacetam, protein oxidation modification.

\begin{abstract}
Abbreviations:
CNS - central nervous system, DM - diabetes mellitus, GABA - gamma-aminobutyric acid, PPO - protein peroxide oxidation, $\mathrm{POM}$ - protein oxidation modification.
\end{abstract}

\section{INTRODUCTION}

Diabetes mellitus (DM) is one of the most concerning diseases nowadays, because of its high prevalence, severe complications, high disability and mortality ${ }^{1,2}$. One of medical-social chronic consequences of DM is encephalopathy, with an advancing course and development of neurodegenerative disorders in the central nervous system (CNS), first of all - in the cerebral cortex and hippocampus ${ }^{3}$. The pathogenic mechanisms of neurodegeneration in DM are hyperglycemia, metabolic imbalance, increase of superoxide radicals, with further activation of lipid peroxide oxidation and protein peroxide oxidation (PPO) ${ }^{4-6}$. Intensification of these processes is the most dangerous link in damage of the nerve cells, by means of inactivation of cytoplasmic enzymes, membrane ionic pumps with gradual involvement of new mechanisms of nerve cells destruction and progressing of cognitive dysfunction.

Among significant causes of susceptibility of DM patients to development of central neurodegeneration are disorders in the balance of inhibitory and irritable processes in the brain. One of the main neuro-mediators of the central inhibition is gamma-aminobutyric acid (GABA) which activates metabolic processes, non linéaires mâles de laboratoire, atteints de neurodégénérescence dans le diabète de type 2 , simulées par la streptozotocine et un régime riche en graisses, ont été étudiées.

Résultats. Chez les rats atteints de diabète de type 2 , le degré d'oxydation au peroxyde des protéines dans le cortex cérébral et l'hippocampe augmente avec l'augmentation du nombre de cellules atteintes de caryopycnose, la diminution de la densité relative de la couleur de la substance tigroïde des neurones et la dénudation partielle des vaisseaux. Après 14 jours d'administration de carbacétam chez des rats diabétiques de type 2 du cortex cérébral et de l'hippocampe, le niveau d'oxydation des protéines par le peroxyde diminue, le nombre de cellules de caryopycnose diminue, la densité relative de la substance tigroïde des neurones augmente, il n'y a pas de dénudation vasculaire.

Conclusions. La réduction de l'intensité des processus d'oxydation des protéines par les peroxydes, les troubles histologiques du cortex cérébral et de l'hippocampe indiquent le potentiel neuroprotecteur du carbacétam dans les cas de neurodégénérescence résultant du diabète de type 2 .

Mots-clés: diabète sucré de type 2, neurodégénérescence, carbacétam, modification de l'oxydation des protéines.

affects the transport and utilization of glucose, increases resistance of the brain cells to hypoxia. The cycle of neuron-astrocytic interrelations is known to play an important role in glucose production and metabolism of both amino acid transmitters: glutamate and GABA - so-called glutamine-glutamate shuttle?

Practically, all the components providing GABAsystem function are known to be present in other systems and organs including the endocrine glands, where this amino acid plays metabolic multifactorial regulatory (or paracrine) role ${ }^{8}$. This neurotransmitter is produced by $\beta$-cells of Langerhans islets, where it plays the role of secretion and function regulator of these structures. The studies conducted on rodents in recent years including the experiments of xenografted human islets in vivo demonstrate that GABA promotes regeneration of $\beta$-cells. Moreover, GABA protects $\beta$-cells of the pancreas against apoptosis induced by cytokines, medicines and other stress factors, possesses anti-inflammatory, immune-regulatory effects 9 .

For a long time, insulin signal mechanisms were considered to be realized in the periphery mainly, though it is finally determined that this hormone causes neuromodulating action in the brain. One of its most interesting effects is modulation of GABA 
current in the hippocampus and many other brain structures ${ }^{10}$.

Thus, pharmacological correctors of GABAergic system today are studied as the means with multiple organ protector properties under conditions of associated pathological processes, and damage of the vital organs in case of type $2 \mathrm{DM}$ in particular.

The obJective OF THE STUDY was to examine carbacetam effect as a new modulator of GABA activity on protein peroxide oxidation and morphological condition of the cerebral cortex and hippocampus, under conditions of experimental neurodegeneration in case of type $2 \mathrm{DM}$ in rats.

\section{Materials AND MEthods}

The experiments were conducted on male rats with the body weight of 0.18-0.20 kg, kept under conditions of natural alternation of day and night. All the experiments were conducted according to the requirements of the European Convention for the Protection of Vertebrate Animals used for Experimental and other Scientific Purposes (18.03.1986); Directive of the EEC No 609 dated 24.11.1986 and the Order of the Health of Ukraine No 690 dated 23.09.2009.

Type $2 \mathrm{DM}$ was simulated by intraperitoneal (i/p) introduction of streptozotocin in a single dose of $30 \mathrm{mg} / \mathrm{kg}$ to rats, which before were kept during 30 days on a high-fat diet with a free access to fructose solution $(200 \mathrm{~g} / \mathrm{L})^{11-13}$. The control group of rats with a standard diet and free access to water were $\mathrm{i} / \mathrm{p}$ injected with citrate buffer solution $(\mathrm{pH}=4.5)$. On the $7^{\text {th }}$ day after streptozotocin injection, type $2 \mathrm{DM}$ was evidenced by glucose concentration in the blood plasma determined by a jeun test. The rats with glycemia lower than $10 \mathrm{mmol} / \mathrm{L}$ were removed from the experiment. On the $7^{\text {th }}$ day after streptozotocin injection, the rats with type $2 \mathrm{DM}$ were randomized into 2 groups: 1 - with introduction of physiological solution; 2 - with i/p introduction of carbacetam in the dose of $5 \mathrm{mg} / \mathrm{kg}$ (for 14 days); the control group received physiological solution.

Euthanasia of rats was performed under light ether narcosis. The brain was removed at cold temperature, carefully washed with cool $0.9 \% \mathrm{NaCl}$ solution, and the cerebral cortex and hippocampus were isolated according to the stereotaxic atlas ${ }^{14}$. Cytoplasmic fraction was isolated by means of differentiated centrifugation method of the homogenate of the examined structures, on a refrigerator centrifuge at $1000 \mathrm{~g}$ per $10 \mathrm{~min}$, followed by $1400 \mathrm{~g}$ per $10 \mathrm{~min}$, at the temperature of $4^{\circ} \mathrm{C}$.

The state of PPO or protein oxidation modification $(\mathrm{POM})$ in the homogenates was assessed by the amount of products of their oxidative modifications by means of spectrophotometry method with the wave length of 370 and $430 \mathrm{~nm}$. The method is based on the reaction of interaction of oxidized amino acid protein residues with 2.4-dinitrophenylhydrazine with formation of its derivatives. Their optical density was measured by means of spectrophotometric method. Aldehyde- or ketone derivatives of a neutral or main character with different ranges of absorption spectrum are known to result from protein oxidation depending on amino acids of a neutral or main character prevailed in their molecules. With $\lambda=370 \mathrm{~nm}$ ketonodinitrophenylhydrazones of a neutral character are determined, with $\lambda=430 \mathrm{~nm}$ - aldehydodinitrophenylhydrazones of the main character ${ }^{15}$. The content of POM was expressed in the units/g of tissue.

The samples of the brain for histological examination were fixed in $10 \%$ neutral formalin solution and, after standard histological conduction, the tissue was placed into paraffin. The paraffin histological sections of tissues of the cerebral cortex $5 \mathrm{~mm}$ thick were prepared by means of the sliding microtome MC-2. After deparaffinization, certain sections were stained with hematoxylin and eosin, others - with neutral red according to Nissl method, in order to determine tigroid substance ${ }^{16}$. Microslides were examined under the light microscope. Digital copies of an optic image were obtained by means of the digital camera Olympus SP550UZ and analyzed by means of a specialized computer program for histological examinations ImageJ (1.48v, free License, W. Rasband, National Institute of Health, USA, 2015) ${ }^{17}$.

The results were statistically processed by means of the parametric $t$-Student criterion, non-parametric Mann-Whitney U-criterion. Changes were considered statistically reliable if $\mathrm{p} \leq 0.05$.

\section{Results AND discussion}

The analysis of the obtained data demonstrated that, in the examined brain, homogenates of the rats with type $2 \mathrm{DM}$ the degree of POM increased (Table 1). In comparison with the control group, the content of proteins of a neutral character increased in the cerebral cortex and hippocampus by 45.2 and 64.7 $\%$, and of the main character - by 50.6 and $39.6 \%$ respectively.

After carbacetam administration in rats with type 2 DM, POM content decreased: registered with $\lambda=370 \mathrm{~nm}-$ by 20.3 and $26 \%$ in the cerebral cortex and hippocampus; with $\lambda=430 \mathrm{~nm}-$ by $22.5 \%$ in both structures of the brain.

In histological specimens of the cerebral cortex and hippocampus of the control group of rats, neurons with karyopyknosis signs were not found. A relative 
Table 1. Carbacetam effect on protein peroxide oxidation in cytosolic fraction of the cerebral cortex and hippocampus of rats with type 2 diabetes mellitus $(\mathrm{M} \pm \mathrm{m}, \mathrm{n}=7)$

\begin{tabular}{ccccc}
\hline Indices & Brain structures & Control & Diabetes mellitus & $\begin{array}{c}\text { Diabetes mellitus } \\
+ \text { carbacetam }\end{array}$ \\
\hline $\begin{array}{c}\text { POM } \lambda=370, \\
\text { unit/g of tissue }\end{array}$ & Cerebral cortex & $30.49 \pm 1.16$ & $44.26 \pm 1.72^{*}$ & $35.26 \pm 1.16^{* * *}$ \\
\cline { 2 - 5 } $\begin{array}{c}\text { POM } \lambda=430, \\
\text { unit } / \mathrm{g} \text { of tissue }\end{array}$ & Cerebral cortex & $30.51 \pm 0.72$ & $33.54 \pm 1.09^{*}$ & $24.83 \pm 0.89^{* * *}$ \\
\cline { 2 - 5 } & Hippocampus & $20.51 \pm 0.72$ & $45.96 \pm 1.67^{*}$ & $34.84 \pm 1.14^{* * *}$ \\
\hline
\end{tabular}

Notes: * - reliability of differences in comparison with the control group of rats, ${ }^{* *}$ - reliability of differences in comparison with the group of DM rats.

density of staining of the neuron tigroid substance in the cerebral cortex was $0.214 \pm 0.0013$ (Fig. 1a, 1b), and in the hippocampus $-0.219 \pm 0.0014$ (Fig. 2a, 2b).

In comparison with the control group of rats against the ground of type $2 \mathrm{DM}$ in the cerebral cortex neurons are found with signs of karyopyknosis in the amount of $4.2 \pm 0.15$ (Fig. 3a), relative density of staining of the neuron tigroid substance $0.115 \pm 0.0010$ (Fig. 3b), which is indicative of the development of neurodegenerative changes.

After carbacetam administration, the percentage of cells with karyopyknosis in the cerebral cortex
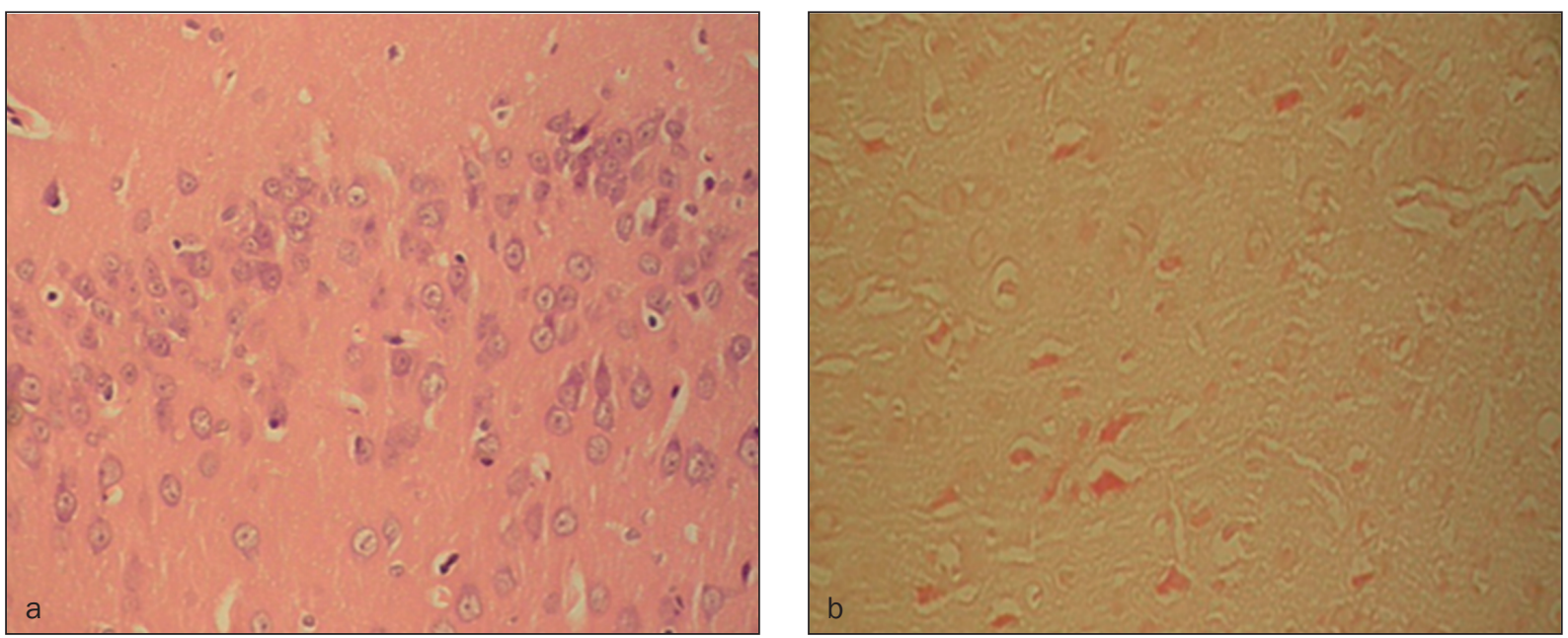

Figure 1. Cerebral cortex of the control group of rats ( $\times 200)$ :

$\mathrm{a}$ - hematoxylin-eosin, $\mathrm{b}$ - neutral red according to Nissl method.
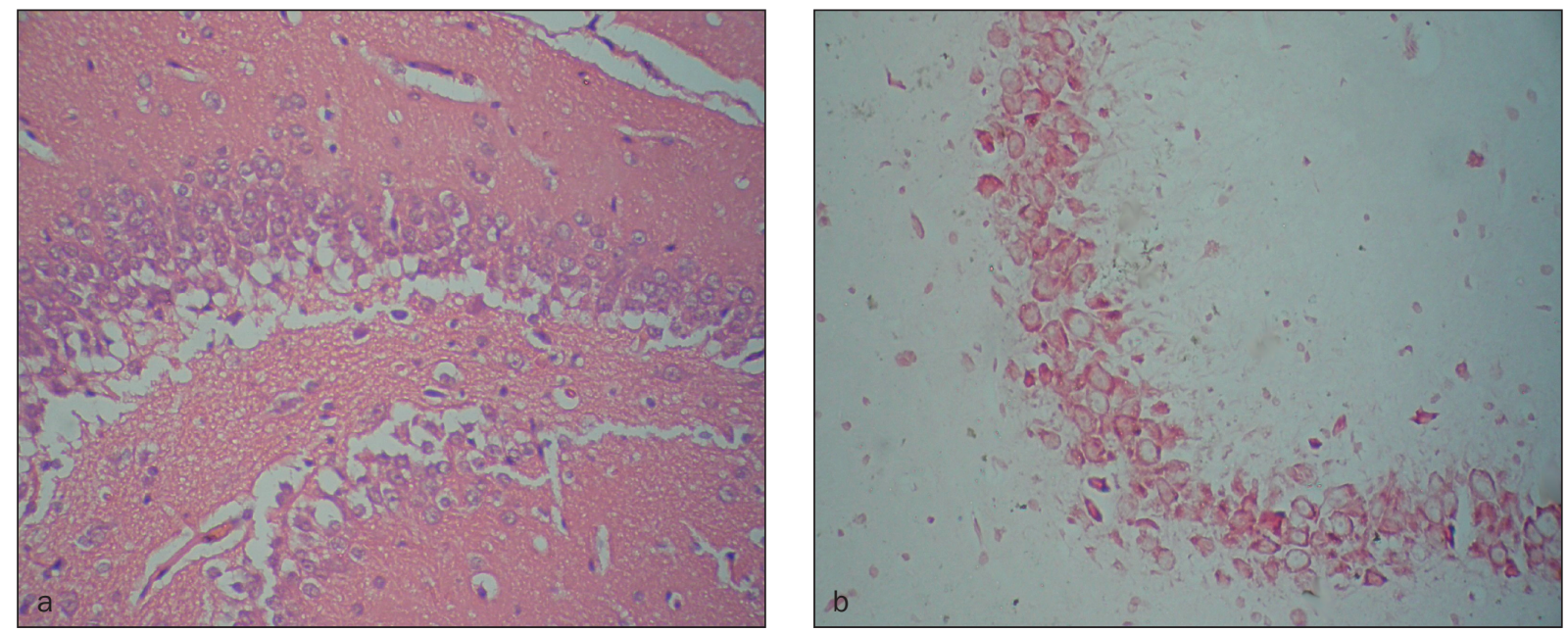

Figure 2. Hippocampus of rats from the control group ( $\times 200)$ : $\mathrm{a}$ - hematoxylin-eosin, $\mathrm{b}$ - neutral red according to Nissl method. 
decreased to $3.4 \pm 0.15$ (Fig. 4a), a relative density of staining of the neuron tigroid substance increased to $0.129 \pm 0.0016$ (Fig. 4b).

Morphological picture of the hippocampus in DM rats was similar to that of the structural changes in the cerebral cortex. Thus, the percentage of neurons with karyopyknosis signs was $4.8 \pm 0.16$ (Fig. 5a), a relative density of staining of the neuron tigroid substance $-0.119 \pm 0.0011$ (Fig. 5b).

After the course of carbacetam administration, the percentage of cells with karyopyknosis decreased to $3.6 \pm 0.14$ (Fig. 6a), and a relative density of staining of the neuron tigroid substance increased to $0.133 \pm 0.0017$ (Fig. 6b). In histological specimens of both examined structures of rats with type $2 \mathrm{DM}$, the signs of partial denudation of vessels (exposure of the vascular endothelium) are found.

Thus, under conditions of type $2 \mathrm{DM}$, intensification of POM processes in the cerebral cortex and hippocampus is one of the mechanisms of neuron damage. After a course (14 days) administration of carbacetam, the degree of POM decreased and the morphological picture of the cerebral cortex and hippocampus improves. Considering the data ${ }^{10}$ concerning the existence of the systems of GABA synthesis and degradation in the walls of the cerebral vessels which plays a considerable role in the regulation of the cerebral circulation including dilation of the cerebral vessels, increase of the volumetric blood flow and oxygen content in the brain cells, a protective role of carbacetam can be affirmed in respect of decreased signs of vascular denudation and reduced pro-oxidant activity in the examined structures of the brain. Therefore, the data presented are indicative of a protective effect of the endogenous modulator of GABA-ergic receptors of carbacetam under conditions of development of central neurodegeneration caused by type $2 \mathrm{DM}$.
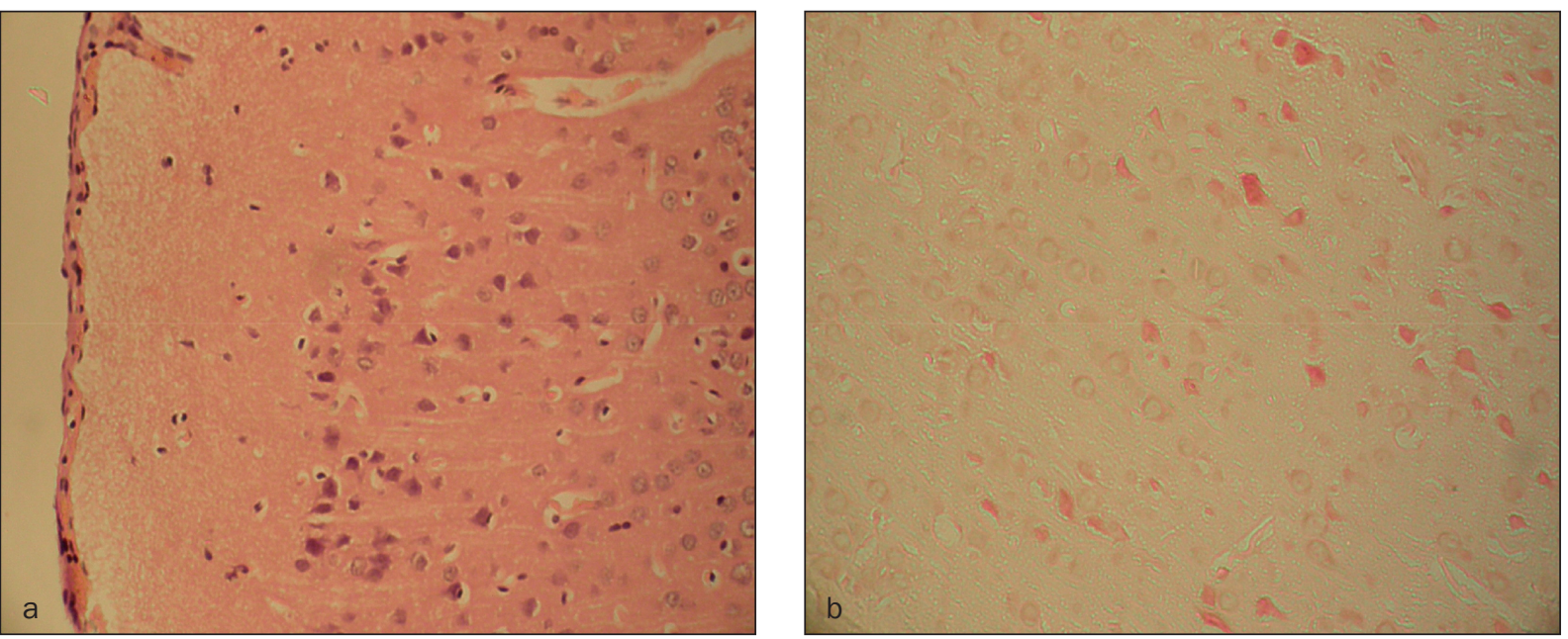

Figure 3. Cerebral cortex of the rats with type 2 DM ( $\times 200)$ : $\mathrm{a}$ - hematoxylin-eosin, $\mathrm{b}$ - neutral red according to Nissl method.
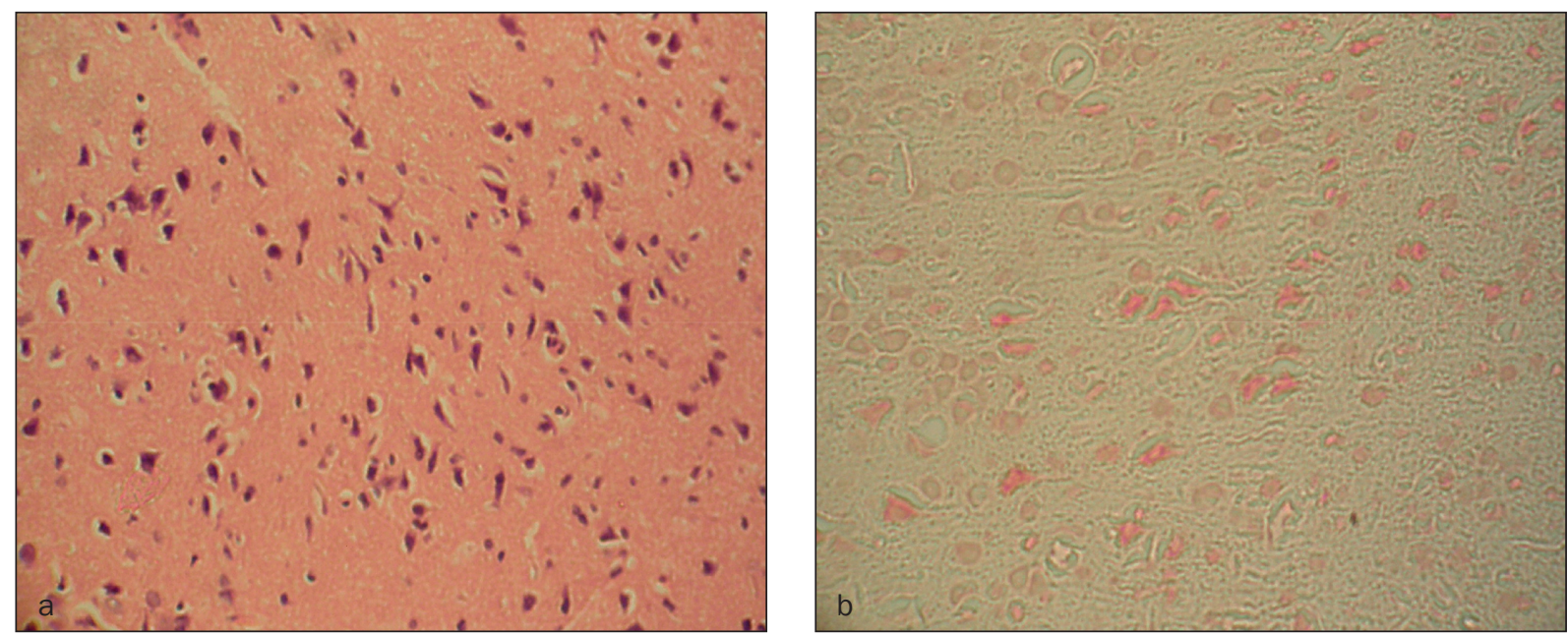

Figure 4. Cerebral cortex of the rats with type $2 \mathrm{DM}$ after carbacetam administration $(\mathrm{x} 200)$ : $\mathrm{a}$ - hematoxylin-eosin, $\mathrm{b}$ - neutral red according to Nissl method. 

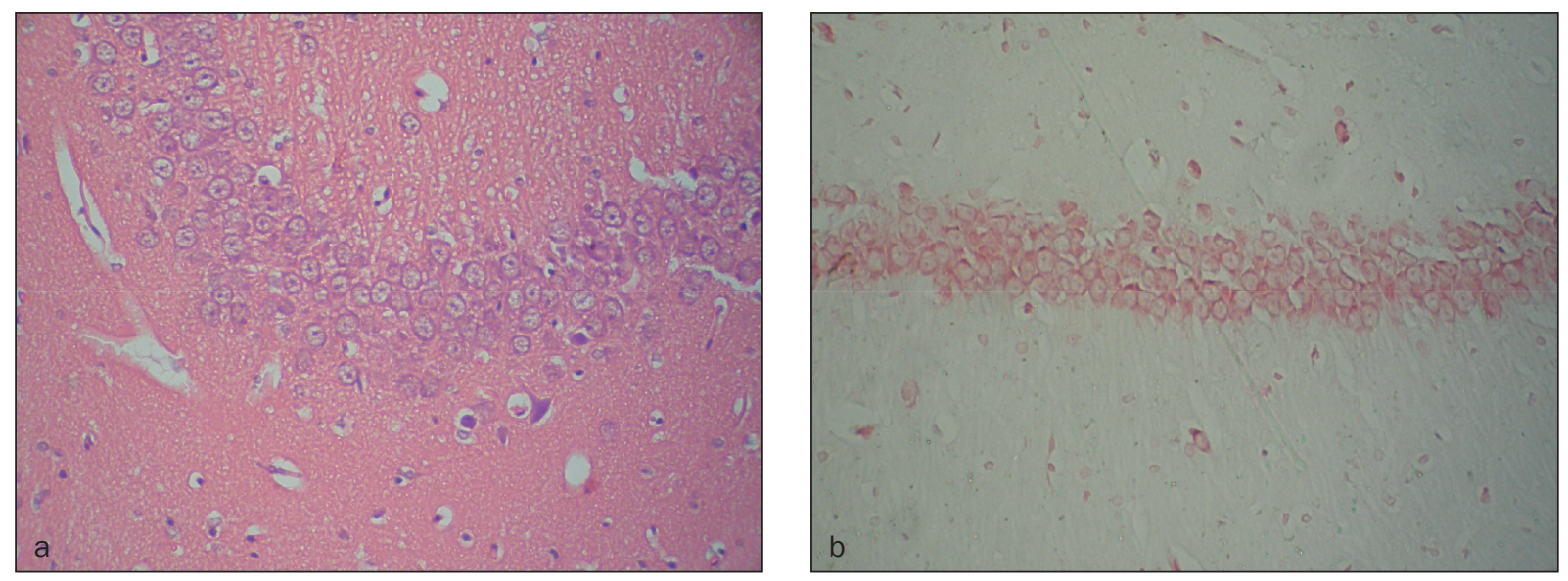

Figure 5. Hippocampus of rats with type 2 DM ( $\times 200)$ :

$\mathrm{a}$ - hematoxylin-eosin, $\mathrm{b}$ - neutral red according to Nissl method.
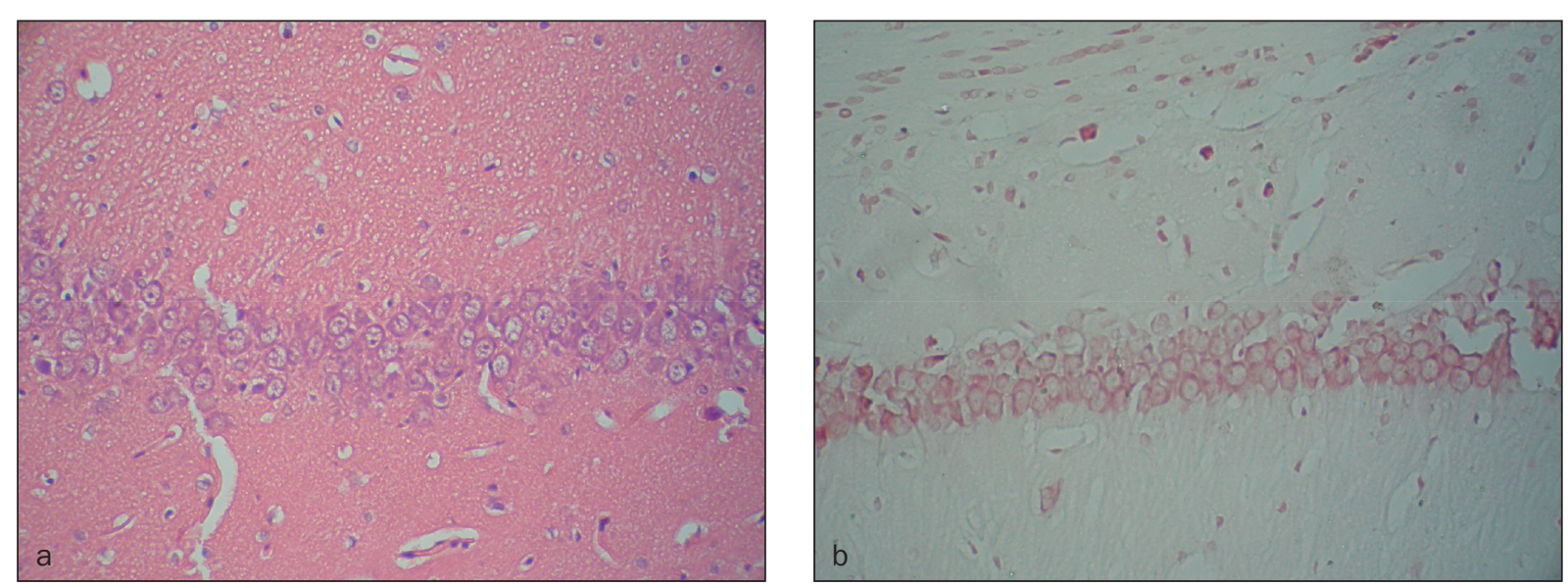

Figure 6. Hippocampus of rats with type 2 DM after carbacetam administration ( $\times 200)$ : $\mathrm{a}$ - hematoxylin-eosin, $\mathrm{b}$ - neutral red according to Nissl method.

\section{Conclusions}

In rats with type 2 diabetes mellitus the degree of protein peroxide oxidation increases in the cerebral cortex and hippocampus which is associated with increased amount of cells with karyopyknosis, decreased relative density of staining of the neuron tigroid substance and partial denudation of vessels.

After carbacetam administration during 14 days in rats with type 2 diabetes mellitus in the cerebral cortex and hippocampus the level of protein peroxide oxidation decreases, the amount of cells with karyopyknosis reduces, a relative density of staining of the neuron tigroid substance increases, and denudation of vessels is lacking.

Decreased intensity of the protein peroxide oxidation processes, histological destruction of the cerebral cortex and hippocampus are indicative of a neuroprotective potential of carbacetam under conditions of neurodegeneration caused by type 2 diabetes mellitus.

\section{Compliance with Ethics Requirements:}

„The authors declare no conflict of interest regarding this article"

"The authors declare that all the procedures and experiments of this study respect the ethical standards in the Helsinki Declaration of 1975, as revised in 2008(5), as well as the national law."

„All institutional and national guidelines for the care and use of laboratory animals were followed"

„No funding for this study" 


\section{References}

1. Ying Liu, Sonica Sayam, Xiaonan Shao, et al. Prevalence of and trends in diabetes among veterans, United States, 2005-2014. Prev Chronic Dis. 2017;14:E135.

2. Diaconu C, Nastasa A, Zaki AR, Arsalan M. Type 2 diabetes: a driver for chronic heart failure. The $2^{\text {nd }}$ International Conference on Interdisciplinary Management of Diabetes Mellitus and its Complications - Diabetes mellitus as cardiovascular disease, INTERDIAB 2016 Proceedings, pag. 201-210. Ed. Niculescu. Editors Serafinceanu C, Negoita O, Elian V.

3. Pashkovska NV. Cognitive impairment in patients with type 2 diabetes mellitus: the role of hypoglycemic therapy. International Journal of Endocrinology. 2018;14(1):76-85.

4. Davies MJ. Protein oxidation and peroxidation. Biochem J. 2016;473(7):805-825.

5. Lennicke C, Rahn J, Heimer N, et al. Redox proteomics: Methods for the identification and enrichment of redox-modified proteins and their applications. Proteomics. 2016;16(2):197-213.

6. Muriach M, Flores-Bellver M, Romero FJ, Barcia JM Diabetes and the brain: oxidative stress, inflammation, and autophagy. Oxid Med Cell Longev. 2014:1-9.

7. Hertz L. The glutamate-glutamine (GABA) cycle: importance of late postnatal development and potential reciprocal interactions between biosynthesis and degradation. Front Endocrinol. 2013;4(59):1-16

8. Takano K, Yatabe MS, ${ }^{\text {Abe }}$ A, et al. Characteristic Expressions of GABA Receptors and GABA Producing/Transporting Molecules in Rat Kidney. PLoS One. 2014;9(9):e105835.
9. Wan Y, Wang Q, Prud'homme GJ. GABAergic system in the endocrine pancreas: a new target for diabetes treatment. Diabetes Metab Syndr Obes. 2015;8:79-87.

10. Trujeque-Ramos S, Castillo-Rolón D, Galarraga E, et al. Insulin regulates $\mathrm{GABA}_{\mathrm{A}}$ receptor-mediated tonic currents in the prefrontal cortex. Front Neurosci. 2018;12:345.

11. Guo X, Wang Y, Wang K, et al. Stability of a type 2 diabetes rat model induced by high-fat diet feeding with low-dose streptozotocin injection. J Zhejiang Univ Sci B. 2018;19(7):559-569.

12. Jurgoński A, Juśkiewicz J, Zduńczyk Z. A High-fat diet differentially affects the gut metabolism and blood lipids of rats depending on the type of dietary fat and carbohydrate. Nutrients. 2014;6(2):616-626.

13. Ruiza GA, Gracia FY. The role of fructose in type 2 diabetes and other metabolic diseases. Journal of Nutrition $\mathcal{E}$ Food Sciences. 2018;8:659.

14. Paxinos G, Watson C. The rat brain in stereotaxic coordinates. 7th Edition. Academic Press. 2013;472 p.

15. Gerush IV, Bevzo VV, Ferenchuk YeO. The effect of melatonin on lipid peroxide oxidation, oxidative modification of proteins and mitochondria swelling in the skeletal muscle tissue of rats under alloxan diabetes. Ukr Biochem J. 2018;90(3):62-69.

16. Venerucci F. Histopathology kits: methods and applications. Bologna, Milan: Bio-Optica. 2016; 98 p.

17. Ferreira T, Rasband W. Image J. User Guide. New York: National Institute of Health. 2012;187 p. 